\title{
The effect of glaze on the quality of frozen stored Alaska pollack (Theragra chalcogramma) fillets under stable and unstable conditions
}

\author{
Peter Žoldoš ${ }^{2}$, Peter Popelka ${ }^{1}$, Slavomír Marcinčák ${ }^{1}$, Jozef Nagy ${ }^{1}$, Lýdia Mesarčová1, \\ Monika Pipová ${ }^{1}$, Pavlína Jevinová ${ }^{1}$, Alena Nagyová 3 , Pavel Mal'a ${ }^{1}$ \\ ${ }^{1}$ Department of Food Hygiene and Technology, University of Veterinary Medicine \\ and Pharmacy in Košice, Slovak Republic \\ ${ }^{2}$ Mraziarne Poprad, Slovak Republic \\ ${ }^{3}$ Department of the Environment, Veterinary Legislation and Economics, \\ University of Veterinary Medicine and Pharmacy in Košice, Slovak Republic
}

Received March 31, 2010

Accepted April 6, 2011

\begin{abstract}
Frozen fillets $(\mathrm{n}=288)$ of Alaska pollack (Theragra chalcogramma) were used to evaluate the effect of glaze on lipid oxidation and microbiological indicators during 6 months of freezing storage under stable $\left(-18{ }^{\circ} \mathrm{C}\right)$ and unstable temperature (varying from -5 to $-18{ }^{\circ} \mathrm{C}$ ) conditions. The amount of glaze, moisture, fat and protein content were measured. Despite the low fat content in Alaska pollack, a positive effect of glazing and stable freezing conditions of storage on the range of oxidative changes of lipids expressed as thiobarbituric acid reactive substances was found. Total counts of viable cells slightly rose before the end of the storage period in both groups with commercially glazed fish. The average counts of psychrotrophs in each group () were at the same level, ranging from $9.1 \times 10^{3} \mathrm{CFU} \cdot \mathrm{g}^{-1}$ to $1.1 \times 10^{4} \mathrm{CFU} \cdot \mathrm{g}^{-1}$. According to the microbiological results fillets stored under unstable conditions were considered to be acceptable, but sensory evaluation showed that at the end of frozen storage they could not be consumed because of rancidity. Based on our results, glaze application ranged from 10 to $15 \%$ guarantee of final quality, however, prevention of temperature fluctuation during storage is important to keep the quality of the frozen fillets. This is the first similar study in Alaska pollack.
\end{abstract}

Fish fillets, glazing, frozen storage, lipid oxidation, temperature fluctuation

One of the main requirements in food industry is to improve the conservation technologies of perishable foods to reach a final product with optimal quality (Chevalier et al. 2000). Freezing followed by cold storage is an efficient method of preservation; however, final quality depends on the initial conditions of foodstuff as well as other factors during freezing, cold storage, and distribution (Johnston et al. 1994). The application of a layer of ice to the surface of frozen products by spraying, brushing on water or by dipping, is widely used to protect the product from the effects of dehydration and oxidation during cold storage. The ice layer sublimes instead of the fish below and it also excludes air from the surface of the fish and thereby reduces the rate of oxidation (Bogh-Sorensen 2002). Good glazing practice can be beneficial, particularly when other aspects of storage and transport are far from ideal, but poor glazing involving partial thawing of the fish and slow refreezing in cold storage may do more harm than good (Johnston et al. 1994).

Although freezing is an effective method of preserving foods, some deterioration in frozen food quality occurs during storage. The extent of quality loss depends on many factors, including the rate of freezing and thawing, storage temperature, temperature fluctuation, transportation, retail display and consumption (Bogh-Sorensen 2002). In fatty species such as herring (Clupeidae), anchovy (Engraulidae), mackerel (Scombridae) and salmon (Salmonidae) the most serious cause of deterioration is oxidation. Despite this fact, also lean fish from Gadidae family are sensitive to lipid oxidation. Lipid oxidation typically results in formation of aldehydes, alkyl radicals and semialdehydes (Chen et al. 
2008). The chemical tests for detecting oxidation and quantifying the extent of oxidation are based upon these changes. Thus, malondialdehyde (MDA), a major degradation product of lipid oxidation, has attracted much attention as a marker for assessing the extent of lipid oxidation (Raharjo and Sofos 1993). Nowadays, the most frequently used method for MDA determination in foods of animal origin is thiobarbituric (TBARS) value estimation (Cordis et al. 1995). However, during frozen storage, Gadidae species can produce an important amount of formaldehyde which was shown to interfere with the traditional spectrophotometric TBARS test (Mendes et al. 2009), and so microbiological and sensory tests provided useful information related to quality loss.

The aim of this study was to estimate the effect of glazing on lipid oxidation in fish fillets during freezing storage under stable and unstable temperature conditions.

\section{Materials and Methods}

Raw material

A total of 288 fillets of Alaska pollack (Theragra chalcogramma) were used to assess the effect of glazing on oxidative changes in lipids during 6 months of storage under frozen conditions. Fillets were divided into 4 groups; 12 fillets were examined in each group every month. The control group (unglazed) was stored under stable freezing conditions; group 1 was manually glazed by dipping and stored under stable freezing conditions; group 2 was industrially glazed and stored under stable freezing conditions; and group 3 was industrially glazed and stored under unstable freezing conditions.

Fillets from group 1 were primarily frozen at $-18^{\circ} \mathrm{C}$ and then manually glazed by dipping in a container with fresh cold drinking water $\left(4^{\circ} \mathrm{C}\right)$. The container was continuously supplied and fitted with overflow. The control group, groups 1 and 2 were stored under stable freezing conditions $\left(-18^{\circ} \mathrm{C}\right)$ and group 3 was stored under unstable conditions varying from -5 to $-18{ }^{\circ} \mathrm{C}$ for 6 months. The temperature was controlled by data logger. When finishing glaze determination, 2 fillets from each group were pooled together and used for chemical and microbiological examinations. Six independent determinations were carried out for each examination.

Glaze determination

Glaze was determined according to the Codex Standard (1995) method. As soon as the package was removed from low temperature storage, the content was placed under a gentle spray of cold water. The fillet was agitated carefully to avoid damage and sprayed until all ice glazes that could be seen or felt were removed. Adhering water was removed by paper towel and weighed on a scale. Unstable temperature conditions rendering changes in stability of glaze were expressed as a free ice sublimate released into the package.

Chemical composition analysis

Moisture content was determined according to the official methods of analysis (AOAC 2007) using the ovendrying method. Crude protein was calculated as N × 6.25 (AOAC 2007). Soxhlet method (ISO 1444 1996) was used to estimate free fat content in fillets. Samples were taken in the first month of frozen storage and analyses were carried out in duplicate.

Determination of thiobarbituric acid reactive substance (TBARS)

Determination of TBARS was performed according to the method described by Marcincak et al. (2004). Malondialdehyde (MDA) was extracted from ground sample when $1.5 \mathrm{~g}$ was weighed into centrifuge tube, and $1 \mathrm{ml} 0.3 \%$ aqueous ethylene diamine tetraacetic acid disodium salt was added immediately. After addition of $5 \mathrm{ml} 0.8 \%$ butylated hydroxytoluene and $8 \mathrm{ml}$ ice-cold $5 \%$ trichloroacetic acid (TCA) homogenization was carried out for $30 \mathrm{~s}$ at maximum speed. When finishing centrifugation $(5 \mathrm{~min}$ at $3500 \times \mathrm{g})$, the top organic layer was discarded and the bottom layer was filtered and diluted with 5\% TCA. After addition of $2 \mathrm{ml}$ of $0.8 \%$ TBA samples and standards were incubated in water bath at $70{ }^{\circ} \mathrm{C}$ for $30 \mathrm{~min}$. Extinction of samples was measured on UVspectrophotometer He $\lambda$ ios $\gamma$ v 4.6 (Thermospectronic, Great Britain) at a wavelength of $532 \mathrm{~nm}$, and expressed as $\mathrm{g}$ of MDA per $1 \mathrm{~kg}$ of sample. Stock solution of MDA was prepared by acid hydrolysis tetramethoxypropane and used for preparation of calibration curve $\left(0.17-0.7 \mu \mathrm{g} \cdot \mathrm{ml}^{-1}\right)$.

Microbiological analysis

The total viable count was determined using the pour plate method according to ISO 4833 (2003) and plates were incubated at $30{ }^{\circ} \mathrm{C}$ for $24-48 \mathrm{~h}$. Plate count method was used also for Enterobacteriaceae (ISO $21528-$ 2 2004), and colonies counted in a solid medium after incubation at $37{ }^{\circ} \mathrm{C}$. Horizontal method was used for enumeration of psychrotrophic bacteria (ISO 17410 2001). Analyses were performed in two parallels and results are expressed as the mean values of replicates.

Sensory evaluation

A scoring test, paired comparison test (ISO 5495 2005), was used for the determination of the sensory quality at the end of the frozen storage period. The thawed fillets were put into aluminium foil and tightly closed. Then the 
samples were thermally treated using hot steam until they achieved the internal temperature of $65^{\circ} \mathrm{C}$ and fried in the oven at $180^{\circ} \mathrm{C}$ for $20 \mathrm{~min}$. After cooking, fillets were cooled to $40^{\circ} \mathrm{C}$ and served to the panellists to evaluate the sensory attributes. Six panellists were selected from among the laboratory staff. Five point intensity scale for each of the following properties (maximum score 25 points): taste, aroma, texture, juiciness, and appearance were applied. When a sample scored badly in one attribute, it was considered not acceptable.

Statistical analysis

Group means and standard deviations were calculated using column statistics, followed by one-way ANOVA analysis of variance, Tukey's multiple comparison test (GraphPad Prism 5, 2007); and treatments were considered significantly different at $P<0.05$.

\section{Results}

The amount of glaze in fish fillets is shown in Table 1. At the end of freezing storage, significant differences were noted among the control group, groups 1 and 2 stored under stable conditions, and group 3 stored under unstable conditions $(P<0.05)$. In group 3 , total glaze fluctuation increased rapidly from the second month of storage. Unstable temperature conditions rendered changes in stability of glaze, expressed as a free ice released from the glaze into the package during frozen storage.

Table 1. Average amount of glaze (\%) in fish fillets

\begin{tabular}{|c|c|c|c|c|c|c|c|}
\hline \multicolumn{8}{|c|}{ Month of storage } \\
\hline & 0 & 1 & 2 & 3 & 4 & 5 & 6 \\
\hline \multirow[t]{2}{*}{ Control } & 5.21 & 5.91 & 4.24 & $6.17 *$ & $7.44 *$ & $8.64 *$ & $8.63 *$ \\
\hline & & & & $0.96 * *$ & $0.83 * *$ & $2.24 * *$ & $1.84 * *$ \\
\hline \multirow[t]{2}{*}{ Group 1} & 6.17 & 13.43 & 13.57 & $14.23 *$ & $15.55^{*}$ & $15.87^{*}$ & $16.99 *$ \\
\hline & & & & $2.12 * *$ & 2.92 & $2.24 * *$ & $1.63 * *$ \\
\hline \multirow[t]{2}{*}{ Group 2} & 9.20 & 10.87 & 9.81 & $11.97 *$ & $15.76^{*}$ & $13.22 *$ & $13.85^{*}$ \\
\hline & & & & $2.68 * *$ & $2.88 * *$ & $2.30 * *$ & $1.25 * *$ \\
\hline \multirow[t]{2}{*}{ Group 3} & 9.10 & 10.52 & $14.17 *$ & $20.94 *$ & $24.63^{*}$ & $27.17^{*}$ & $25.06^{*}$ \\
\hline & & & $2.10 * *$ & $8.11 * *$ & $13.40 * *$ & $15.10 * *$ & $10.68 * *$ \\
\hline
\end{tabular}

*Total glaze including sublimate, $* *$ Sublimate expressed as ice released into the package

Table 2. Chemical composition of fish fillets

\begin{tabular}{lccc}
\hline Sample & \% Moisture & \% Protein & $\%$ Fat \\
\hline Control & $86.73 \pm 1.041$ & $14.83 \pm 1.370$ & $0.650 \pm 0.099$ \\
Group 1 & $86.61 \pm 2.186$ & $15.02 \pm 2.118$ & $0.567 \pm 0.101$ \\
Group 2 & $84.26 \pm 0.720$ & $16.08 \pm 2.496$ & $0.583 \pm 0.091$ \\
Group 3 & $85.24 \pm 1.982$ & $16.85 \pm 2.376$ & $0.560 \pm 0.160$ \\
\hline
\end{tabular}

$\mathrm{n}=6$, mean $\pm \mathrm{SD}$

Table 2 shows the chemical composition when no interaction $(P>0.05)$ for moisture, protein and fat content was found. The average fat content ranged from 0.56 up to $0.65 \%$.

Results of TBARS determination in stored samples are shown in Table 3. In glazed samples (group 1 and 2), lower amounts of MDA were determined compared to control unglazed samples during the whole period of frozen storage. Significant differences among groups were found within 2 months of storage $(P<0.05)$ and during the following period the differences were enhanced. Massive lipid oxidation in group 3 caused by unstable temperature was higher compared to glazed groups and the control unglazed group. 
Table 3. Lipid oxidation (expressed as an amount of malondialdehyde $\mathrm{mg} \cdot \mathrm{kg}^{-1}$ ) in fish fillets

\begin{tabular}{lccccccc}
\hline & \multicolumn{7}{c}{ Month of storage } \\
& 0 & 1 & 2 & 3 & 4 & 5 & 6 \\
\hline Control & 0.166 & 0.172 & 0.204 & 0.328 & 0.371 & 0.357 & 0.400 \\
& $\pm 0.021^{\mathrm{a} 1}$ & $\pm 0.011^{\mathrm{a} 1}$ & $\pm 0.013^{\mathrm{b} 2}$ & $\pm 0.018^{\mathrm{b} 3}$ & $\pm 0.027^{\mathrm{b} 3}$ & $\pm 0.027^{\mathrm{b} 3}$ & $\pm 0.024^{\mathrm{b} 3}$ \\
Group 1 & 0.162 & 0.159 & 0.165 & 0.163 & 0.191 & 0.235 & 0.246 \\
& $\pm 0.019^{\mathrm{a} 1}$ & $\pm 0.015^{\mathrm{a} 1}$ & $\pm 0.007^{\mathrm{a} 1}$ & $\pm 0.015^{\mathrm{a} 1}$ & $\pm 0.007^{\mathrm{a} 2}$ & $\pm 0.040^{\mathrm{a} 2}$ & $\pm 0.054^{\mathrm{a} 2}$ \\
Group 2 & 0.149 & 0.150 & $0.166 \pm$ & 0.181 & 0.203 & 0.268 & 0.249 \\
& $\pm 0.029^{\mathrm{a} 1}$ & $\pm 0.008^{\mathrm{a} 1}$ & $0.010^{\mathrm{a} 1}$ & $\pm 0.006^{\mathrm{a} 2}$ & $\pm 0.024^{\mathrm{a} 2}$ & $\pm 0.021^{\mathrm{a} 2}$ & $\pm 0.012^{\mathrm{a} 2}$ \\
Group 3 & 0.149 & 0.196 & 0.225 & 0.376 & 0.429 & 0.465 & 0.592 \\
& $\pm 0.021^{\mathrm{a} 1}$ & $\pm 0.014^{\mathrm{a} 1}$ & $\pm 0.005^{\mathrm{b} 2}$ & $\pm 0.024^{\mathrm{b} 3}$ & $\pm 0.05^{\mathrm{b} 3}$ & $\pm 0.041^{\mathrm{c} 3}$ & $\pm 0.036^{\mathrm{c} 3}$ \\
\hline
\end{tabular}

a,b,c- values in column are significantly different, ${ }^{1,2,3}$ - values in row are significant

Table 4. Sensory evaluation of fish fillets at the end of frozen storage using five point descriptive methods (maximum 25 points)

\begin{tabular}{lll}
\hline & Boiling method & Frying method \\
\hline Control & $21.50 \pm 1.291^{\mathrm{a}}$ & $18.50 \pm 1.291^{\mathrm{b}}$ \\
Group 1 & $21.75 \pm 1.500^{\mathrm{a}}$ & $22.50 \pm 1.732^{\mathrm{a}}$ \\
Group 2 & $21.50 \pm 1.915^{\mathrm{a}}$ & $20.00 \pm 1.826^{\mathrm{ab}}$ \\
Group 3 & $18.50 \pm 1.414^{\mathrm{b}}$ & $14.50 \pm 2.380^{\mathrm{c}}$ \\
\hline
\end{tabular}

a,b,c - values in column are significantly different
Total counts of viable cells (TVC) remained unchanged in both the control group and group 1 within the six-month storage period. On the other hand, TVCs rose considerably before the end of the storage period in both groups with commercially glazed fish. Although TVC changed also in group 3 before the end of the storage period, the average counts of psychrotrophs were at the same level in each group (they ranged from $9.1 \times 10^{3} \mathrm{CFU} \cdot \mathrm{g}^{-1}$ to $1.1 \times 10^{4} \mathrm{CFU} \cdot \mathrm{g}^{-1}$ ). The counts of Enterobacteriaceae did not exceed the value of $1.5 \times 10^{2} \mathrm{CFU} \cdot \mathrm{g}^{-1}$ in any group with the only exception in month 6 for group $3\left(2.0 \times 10^{3} \mathrm{CFU} \cdot \mathrm{g}^{-1}\right)$.

The results of sensory evaluation of fillets after 6 months of storage are given in Table 4 . Glazed fillets stored at stable freezing conditions using the frying method were generally more desirable than the control group $(P<0.05)$. Significant differences $(P<0.05)$ were found when the fillets stored at unstable conditions were compared to the above mentioned groups. Sensory analysis showed that at the end of frozen storage these samples scored badly in one (odour) or two attributes (odour and taste) and they were not acceptable because of rancidity.

\section{Discussion}

Water released during the process of thawing is often considered as a negative effect of glazing by consumers. Despite this fact, some species of fish and fish products should be glazed and stored taking into account the preservation of acceptable chemical, bacteriological and organoleptic properties during long-term storage and distribution. The amount of glaze differed according to the method of glazing and changes were accelerated during the time of storage at unstable conditions. The glaze content normally ranges at $8-12 \%$ of the net weight; however, abuse has been reported in recent years, with glaze coatings as thick as $25-45 \%$ of the net weight, causing economic loss for consumers (Hui et al. 2004). Our results demonstrate the importance of stable storage temperature to minimize glaze variation. If the product is subjected to inadequate cold storage, the glaze will evaporate instead of the tissue water itself (Jacobsen and Fossan 2001).

Fish of the family Gadidae are considered lean fish with the fat content of up to $2 \%$. The lipid contents, expressed on a wet weight basis, were as low as $0.79 \pm 0.17 \mathrm{~g}$ per $100 \mathrm{~g}$ for Alaska pollack fillets (Huynh and Kitts 2009). As the determined fat content was low, 
it can be stated that the glazing of fish fillets had a significant positive effect on decreasing the lipid oxidation and production of metabolites of fat deterioration. It has been proposed that a maximum TBARS value (indicating the good quality of fish) is $5 \mathrm{mg}$ MDA per $1 \mathrm{~kg}$, whereas fish may be consumed up to a level of $8 \mathrm{mg} \mathrm{MDA} / \mathrm{kg}$ (Schormüller 1969).

However, bacterial decomposition was the same, physical and chemical changes (oxidative rancidity and sensory properties) during extended frozen storage impaired the quality of thawed fish fillets. Usually, it is observed that spoilage of iced cod fish fillets occurs when the TVC reaches about $10^{6} \mathrm{CFU} \cdot \mathrm{g}^{-1}$ (Licciardello and D'Entremont 1987). When the influence of freezing $\left(-20{ }^{\circ} \mathrm{C}\right.$ for six months) was investigated on the susceptibility of hake to chemical, microbiological and sensory spoilage, the levels of chemical indicators (amines) decreased to lower values in frozen-thawed hake in accordance with the delay of microbial development. On the contrary, sensory spoilage occurred earlier and therefore, the usual accepted or regulated limits of chemical and microbiological indicators would not be suitable for freshness assessment of frozen-thawed hake (Baixas-Nogueras et al. 2007).

In conclusion, the keeping of rules and conditions of glazing of fish can be profitable in case of stable conditions of storage and transportation. On the other hand, when the rules are not kept, partial thawing of fish and repeated freezing as well as too slow thawing after glazing can have a negative effect on acceptance of products.

\section{References}

AOAC 2007: Official methods of analysis, Gaithersburg, Maryland, USA, Secs. 937.07, 950.46, 960.39, 928.08

Baixas-Nogueras S, Bover-Cid S, Veciana-Nogues M, Vidal-Carou M 2007: Effects of previous frozen storage on chemical, microbiological and sensory changes during chilled storage of Mediterranean hake (Merluccius merluccius) after thawing. Eur Food Res Technol A 226: 287-293

Bogh-Sorensen L 2002: Recommendations for the processing and handling of frozen foods. International Institute of Refrigeration, Paris

Chen YC, Nguyen J, Semmens K, Beamer S, Jaczynski J 2008: Chemical changes in omega-3-enhanced farmed rainbow trout (Oncorhynchus mykiss) fillets during abusive-temperature storage. Food Control 19: 599-608

Chevalier D, Le Bail A, Ghoul M 2000: Freezing and ice crystals formed in a cylindrical food model: Part I. Freezing at atmosphere pressure. J Food Eng 46: 277-285

Codex Standard, 190 - 1995: Codex General Standard for Quick frozen fish fillets.

Cordis AD, Maulik N, Das DK 1995: Detection of oxidative stress in heart by estimating the dinitrophenylhydrazine derivative of malonaldehyde. J Mol Cell Cardiol 21: 1645-1653

Hui YH, Cornillon P, Legarreta IG, Lim M, Murrell KD, Nip WK 2004: Handbook of frozen foods, vol. 133, Part IV: Frozen seafoods. Marcel Dekker Incorporated, New York, 1293 p.

Huynh MD, Kitts DD 2009: Evaluating nutritional quality of pacific fish species from fatty acid signatures. Food Chem 114: 912-918

ISO 1444 1996: Meat and meat products: Determination of free lipids.

ISO 17410 2001: Microbiology of food and animal feeding stuffs: Horizontal method for the enumeration of psychrotrophic microorganisms.

ISO 4833 2003: Microbiology of food and animal feeding stuffs: Horizontal method for the enumeration of microorganisms - Colony-count technique at $30^{\circ} \mathrm{C}$.

ISO 21528-2 2004: Microbiology of food and animal feeding stuffs: Horizontal methods for the detection and enumeration of Enterobacteriaceae - Part 2: Colony-count method.

ISO 5495 2005: Sensory analysis - Methodology - Paired comparison test.

Jacobsen S, Fossan KM 2001: Temporal variations in the glaze uptake on individually quick frozen prawns as monitored by the Codex standard and the enthalpy method. J Food Eng 48: 227-233

Johnston WA, Nicholson FJ, Roger A, Stroud GD 1994: Freezing and refrigerated storage in fisheries. FAO Fisheries Technical Paper No. 340, FAO, Rome, 143 p.

Licciardello JJ, D'Entremont DL 1987: Bacterial growth rate in iced fresh and frozen-thawed Atlantic cod, Gadus morhua. Mar Fish Rev 49: 43-45

Marcinčák S, Sokol J, Bystrický P, Popelka P, Turek P, Bhide M, Máté D 2004: Determination of lipid oxidation level in broiler meat by liquid chromatography. J AOAC Int 87: 1148-1152

Mendes R, Cardoso C, Pestana C 2009: Measurement of malondialdehyde in fish: A comparison study between HPLC methods and the traditional spectrophotometric test. Food Chem 112: 1038-1045 
Raharjo S, Sofos JN 1993: Methodology for measuring malonaldehyde as a product of lipid peroxidation in muscle tissues: A review. Meat Sci 35: 145-169

Schormüller J 1969: Handbuch der lebensmittelchemie (Band IV). Springer Verlag, Berlin - Heidelberg - New York 